\title{
The Degree of Using Authentic Evaluation by International Schools Teachers in the Middle Schools from Their Viewpoint in Aljama 'a District
}

\author{
Nancy Drae* Fawaz Shahada \\ Faculty of Educational Sciences, Middle East University PO box 11831, Amman, Jordan
}

\begin{abstract}
This study aimed to identify the degree of using of authentic evaluation by teachers of international schools in the middle school from the viewpoint of the teachers themselves in Aljama 'a district. The study used the descriptive approach, through the development of the study tool, which is a questionnaire consisting of 50 paragraphs distributed in (5) fields, after confirming its sincerity and consistency. The sample of the study consisted of 360 male and female teachers of the middle school, who were chosen from international schools in Aljama 'a district. The results of the study showed that the degree of use of international school teachers to realistic evaluation in the middle school from the point of view of the teachers themselves was high, as it showed the presence of a statistically significant difference in the degree of use of international school teachers due to the gender variable in favor of females, and the absence of a statistically significant difference attributed to the variable (experience) and the interaction between the two variables (gender and experience), and the absence of statistically significant differences attributed to the variable for academic specialization. The study suggested several recommendations, the most important of which is to enhance and encourage teachers to use realistic evaluation as an alternative to traditional evaluation because it has a great impact in increasing the interaction between the teacher and the student and thus increasing the desired results from the education process.
\end{abstract}

Keywords: Alternative assessment, International Schools, Middle School.

DOI: $10.7176 / \mathrm{JEP} / 12-10-07$

Publication date: April $30^{\text {th }} 2021$

\subsection{Introduction}

The world today is witnessing a tremendous new technological revolution that includes a scientific revolution in information technology. In the modern era, humans are facing amazing technological developments at an accelerated pace, in all vital fields, and this development extended to the field of learning and education, and it became one of the most important fields affected by this development.

The recent developments in education have affected teachers in the evaluation process which prompted them to use new strategies and methods of evaluation to keep pace with technological progress and consequently, scientific and knowledge development (Al Mousa, 2014).

Evaluation is considered one of the most important stages of any educational system based on inputs, processes and outputs, where at the beginning of each stage there are evaluation processes to know the basis on which the system will be built, in addition to the evaluation that takes place during the course of the system's operations to identify weaknesses and work to address them, and strengths to strengthen them, there is a final evaluation to determine the suitability of the system and its success or lack of success (Al-Kubaisi, 2014).

Traditional evaluation methods focus on student achievement without taking into account individual differences, and focus on the cognitive side, neglecting the student's skillful and emotional side, which must be taken into account to achieve comprehensive and integrated growth. Evaluation was based on paper-and-pencil tests, and tests of right and wrong, which only measure knowledge and minimum levels of thinking (Posner, 2016).

With the development of the concept of learning and the accompanying change in teaching and evaluation methods, the focus on the student has become an important element in the educational process, and the evaluation concept has evolved to measure the three aspects of learning: cognitive, skillful and emotional skills. The evaluation in its modern sense has become based on taking into account individual differences among students, focusing on measuring the higher thinking skills of the student and the extent of development in his/her personality as a result of the occurrence of learning, and his ability to employ what he learns in similar life circumstances, and this is all a result of the acceleration in the amount of knowledge and changes facing the student in the Age of Technology (Ministry of Education, 2013).

Therefore, the evaluation is no longer limited to measuring the student's academic achievement in various subjects and fields. Rather, it goes beyond it to measure the characteristics of the student's personality in all its aspects, thus expanding its fields and diversifying its methods (Mansour, 2007).

Realistic evaluation or alternative evaluation is a new trend in educational thought and a fundamental shift in the prevailing traditional practices in measuring and evaluating learners and their performance in the different 
stages of the educational process. Whereas, alternative evaluation requires the learner to demonstrate his/her skills and knowledge, and his/her performance through the formation of a meaningful product, or the completion of a dynamic task using higher mental processes and problem-solving, and this requires meaningful applications that go beyond the limits of the activity performed by the learner as realistic evaluation is known as a continuous process that includes the student and the teacher in making decisions and judgments about the student's progress using unconventional strategies, and that the philosophy of realistic evaluation is based on the belief that the student's learning and academic progress can be evaluated through actions and tasks that require activity, such as researching and investigating problems carrying out experiments, and this method of evaluating and reflecting student performance. It shifts from a behavioral view to a constructive view of learning (Jaber, 2006).

Since realistic evaluation is an integral part of the education system, the researcher had a desire to investigate the degree of use of international school teachers for realistic evaluation in the upper primary stage from the viewpoint of the teachers themselves in Aljama 'a brigade.

Al-Zaubi (2013) conducted a study aimed at revealing the degree of mathematics teacher's knowledge of the higher basic grades in Jordan and their practice of realistic evaluation' strategies and tools, in addition to identifying the impact of gender variables, academic qualification and service on the degree of knowledge of these strategies and tools. The study used the descriptive method, and the questionnaire tool consisting of four parts was used. The validity and stability of the questionnaire were verified. A note card was also developed in which lessons were watched and followed by teachers applying realistic evaluation strategies and tools. The sample of the study consisted of (91) math teachers from the Directorate of Education in the Governorate of Irbid during the second semester 2011/2012. The results of the study showed that the degree of use is still lower than expected, and the study showed that the degree of knowledge and the degree of use of the observation method was $(100 \%)$ while the degree of knowledge and the degree of use was approximately $(0 \%)$ for the student diary tool. The results also showed that the main reasons limiting the use of the realistic evaluation method from the teachers' point of view were their exhaustion of time and effort, the abundance of burdens placed on them, and the momentum of the curriculum, as well as the results did not show an effect of any of the variables: gender, service, and qualification, but there was an effect of the interaction of the gender and the qualification in the section devoted to the opinions of male and female teachers about realistic evaluation.

Awawda (2015) conducted a study aimed at measuring the degree of practice of Arabic language and Islamic studies teachers in middle school in Dammam for realistic evaluation strategies: performance-based evaluation, paper and pen evaluation, observation evaluation, evaluation by communication, and self-evaluation, in addition to studying the impact of the study variables: Gender, educational qualification and educational service in the degree to which these strategies are practiced. The study used the descriptive method, and a tool was developed and designed for the study, which is a questionnaire, and the study was applied on a random sample of (199) male and female teachers in schools affiliated to Dammam governorate. The results showed that the practice of male and female teachers of realistic evaluation strategies came with a moderate degree, with an arithmetic mean of (7.3), the results also showed a statistically significant difference in the degree of practicing realistic evaluation strategies due to the gender variable in favor of males, and the educational service for the benefit of male and female teachers with experience of less than (5 years) due to the effect of educational qualification at the level of significance, while there is no statistically significant difference in the educational qualification variable.

Bantlo (2016) conducted a study aimed at describing the experiences of learners of a realistic education system (realistic evaluation) in their pursuit of education, and the mechanisms of their facing the challenges in their education to pursuit their dreams and inspirations in life. Realistic evaluation from the various realistic evaluation centers of the Ministry of Education - Department of Sarangani, Philippines for the academic year 2015-2016. The results of this study showed the necessity of conducting a study dealing with the criteria for realistic assessment teachers that sheds light on their personal experiences and the challenges they face in implementing a realistic evaluation program in schools.

In terms of the goal: The current study is similar in its aim to study the degree of employing teachers for realistic evaluation with the study of Awawda (2015), and it differed in its goal with the study of Al-Zaubi (2013) and Bantlo (2016).

In terms of the sample: This study differed with all the previous studies.

In terms of the tool: the current study tool is similar in designing a questionnaire to Al-Zaubi (2013), Awawda (2015) and disagreed with the Bantlo (2016) study.

Regarding the method used: the current study used the survey descriptive method and it was similar in approach with all the previous studies.

The current study was distinguished by being the first study - to the best of the researcher's knowledge which aimed to find out the degree of employment of international school teachers for realistic evaluation in the upper elementary stage in the Aljama 'a district, as it surveyed the opinions of all specializations of teachers of the higher basic stage (scientific and humanitarian) in international schools. 


\section{2: The study Problem:}

Due to the rapid development in education and the introduction of technology into the educational system, there was a need for an evolution in educational and evaluation methods, and because the international schools in the Aljama 'a district use the English language in their teaching of all subjects of the foreign program, and since the humanitarian and scientific methods that are taught to students whose mother tongue is not English, especially in the primary stage of education, there had to be evaluation methods that help the teacher and the student to know the extent of the student's development of the student's language and his ability to use the language in daily life. This type of evaluation should be continuous, in order to identify the weaknesses of students and work to strengthen them. Therefore, the teacher has to develop the evaluation methods used when evaluating their students, and that these methods are inclusive of all aspects of their personality, and accordingly, the realistic evaluation is a type of modern evaluation that is contrary to the traditional evaluation systems that focus on the cognitive aspect only of the student's personality and can be used strongly in these schools and in the various educational stages.

In general, student achievement in schools, including international schools, is measured through the traditional evaluation that depends directly on measuring the cognitive aspect, and this does not correspond to the English language taught in schools that include skills and attitudes in addition to theoretical knowledge, and for the evaluation to be successful and fruitful, the teacher must be aware of the most important outputs of the system, the points that should be focused on, and familiar with more than one evaluation method and the various stages of the educational process (Abdel-Hay, 2017). On the other hand, each educational stage has a special method of evaluation according to the age level of students of that stage, as the tests are nothing but a form of evaluation (Zaitoun, 2003)

Through the researcher's work as a teacher in an international school, she noticed that most teachers rely on traditional achievement tests as a tool for evaluating students, because they are not aware of realistic evaluation tools, or are not convinced of using these tools or because it constitutes in their view an additional burden, more effort and greater preparation, as well as some teachers use these tools in a random way that does not serve the process of evaluating students' performance, and while it appeared through the researcher's review of previous studies that there was a weakness in cultural awareness about this type of evaluation in the educational field and the resulting different reactions and multi-directional opinions among supporters, opponents and conservatives.

The most problematic of this type of evaluation is the failure to activate its procedures in learning environments, so the researcher felt a sense of the problem of the study to reveal the degree to which teachers practice realistic evaluation from their point of view to reach a clear vision based on scientific foundations that contribute to directing the process of education and evaluation. After reviewing the literature on the subject, many local, Arab and international studies have recommended the need to use realistic evaluation in schools and in the different educational stages (Al-Mahrooqi \& Denman, 2018). More studies should be conducted related to the use of realistic evaluation and the degree to which school teachers use realistic evaluation strategies in the elementary stage in schools. The study of Nasri et al. (2010) also recommends the need to research the use of teachers for realistic evaluation in schools.

Hence the problem of the study to investigate the extent to which teachers of basic education in the Hashemite Kingdom of Jordan use realistic evaluation strategies from the teachers' point of view because they are responsible for implementing realistic evaluation programs in their schools in order to reach a clear vision based on scientific foundations that contribute to directing the teaching and evaluation process for the purposes of advancement.

The aim of the study and its questions:

The study aimed to investigate the degree to which international schools' teachers use realistic evaluation in the elementary stage in international schools and their attitudes towards it by answering the following questions

The first question: To what degree do international school teachers use realistic assessment in the upper elementary stage?

The second question: Does the degree to which international school teachers use realistic assessments in the upper elementary stage differ according to gender, years of service or the interaction between them?

The third question: Does the degree to which international school teachers use realistic assessment in the upper elementary stage differ according to the academic specialization?

\section{3: The importance of this study:}

The importance of this study stems from the importance of its topic, which is realistic evaluation or alternative evaluation, which is one of the main topics in the educational learning process, and which aims to improve the learning process, and focus on the student's performance and real level, especially in the primary stage.

The theoretical importance of the study lies in the fact that it may contribute to highlighting the importance of realistic evaluation as it is one of the modern strategies followed by evaluation from the viewpoint of teachers of the higher basic stage working in international schools in the university district, and thus the study contributes 
to providing practical and research horizons in the field of evaluation. Providing the competent bodies in the Ministry of Education (supervisors, curriculum management examination and evaluation administration) with a clear and true picture of the reality of teachers' use of realistic evaluation in the upper primary stage in international schools and identifying weaknesses in the evaluation process in order to focus on them and take them into account in teacher training programs.

As for the practical importance, the results that result from this study may benefit the teacher in improving his/her performance, developing his/her evaluation skills and the method of evaluation, and also in preparing programs and special training studies for realistic evaluation. This depends on the degree to which they use it, and its effect on students' attitudes and educational achievement.

\section{4: The limits of the study:}

The limitations of the current study were as follows:

Objective boundary: Five types of realistic evaluation strategies are the paper-and- pencil evaluation strategy, the performance-based evaluation strategy, the observation evaluation strategy, the self-review evaluation strategy and the communication evaluation strategy.

The human limit: A sample of international school teachers studying in the upper primary stage in the university district.

Spatial boundary: The international schools in the university district in the capital Amman.

The time limit: Second Semester2019/2020.

Study limitations: The results of the current study are determined by the degree of responses of the individuals of its sample, the nature of its tools. The results of the current study can be generalized to societies similar to their own societies, in light of the validity and stability of the study tool.

\section{5: Study terminology and procedural definitions:}

The current study included a set of concepts and terms that were conceptually and procedurally defined as follows:

Realistic (Authentic Assessment): It is defined as a form of evaluation in which students are required to perform realistic tasks that show a useful application of basic knowledge and skills. The evaluation usually includes a task for students and an evaluation form for their performance in this task, and it consists of attractive or worthy problems or questions of interest, as students must during their performance the mission use knowledge to design presentations effectively and creatively. The tasks are either identical or similar to the kinds of problems faced by senior citizens, consumers, or professionals in the field (Wiggins, 2006).

In a realistic evaluation, the student builds the answer to the questions asked through a task or a group of tasks, and teachers often use one of the following types of realistic evaluation: such as (performance evaluation, project-based evaluation), progressive measurement of performance (Rubric, Portfolio, CAT technology, rating scales, exhibitions, peer evaluation, and self-evaluation) (Abboud, 2016).

A realistic procedural evaluation is defined as an evaluation that makes the trainees indulge in tasks that are of value and meaning to them, so that they appear as learning activities and not as secret tests. In which the trainees practice higher thinking skills and harmonize a wide range of knowledge in order to formulate judgments, make decisions or solve real life problems that they live, and thus develop their ability to think contemplative which helps them to process, critique and analyze information (Gottlieb, 2016) and is measured by intelligent assessment tools.

Degree of use: The extent to which teachers of the upper primary stage practice realistic evaluation in terms of planning, implementation, and follow-up of results.

Strategies: A comprehensive and organized plan, which means planning and defining the means that must be taken in order to achieve long-term goals.

Teachers in the upper primary stage: They are the teachers who teach the higher basic grades (seventh, eighth, and ninth).

\section{Study design and procedures}

\section{1: Study Design:}

2.1.1: Study Approach:

The study used the descriptive method. The survey is relevant to this type of study.

2.1.2: Study community:

The study community consisted of all the teachers of international schools for the upper basic stage in the Aljama' a district in the capital Amman for the year 2019/2020. The number of teachers in international schools in the Aljama 'a brigade reached (8239) for the year 2018/2019, and information was collected from the statistics of the Jordanian Ministry of Education and the Directorate of Private Education. 


\subsection{3: The study sample:}

The study sample consisted of (368) an international school teacher for the secondary upper primary stage For the Directorate of Education in the Aljama 'a District, they were randomly selected during the second semester of the 2019/2020 academic year, and the sample size was determined according to the Krejcie and Morgan schedule (Krejcie \& Morgan, 1970).

The arithmetic indications of the demographic variables (frequency and percentage of the study sample were as shown in Table 1 below:

Table 1: Distribution of the study members according to gender, specialization, and years of service

\begin{tabular}{|l|l|l|}
\hline Gender & Frequency & Percentage \\
\hline Fales & 130 & $\mathbf{3 5 . 3}$ \\
\hline Total & 238 & $\mathbf{6 4 . 7}$ \\
\hline Specialization & 368 & $\mathbf{1 0 0}$ \\
\hline Humanitarian & Frequency & Percentage \\
\hline Scientific & 167 & $\mathbf{4 5 . 4}$ \\
\hline Total & 201 & $\mathbf{5 4 . 6}$ \\
\hline Years of service & 368 & $\mathbf{1 0 0 . 0}$ \\
\hline Less than 5 years & Frequency & Percentage \\
\hline From 5-10 years & 111 & $\mathbf{3 0 . 2}$ \\
\hline More than 10 Years & 134 & $\mathbf{3 6 . 4}$ \\
\hline Total & 123 & $\mathbf{3 3 . 4}$ \\
\hline
\end{tabular}

\section{2: Study tool:}

By reviewing the educational literature on the previous studies of relevance, the researcher benefited from the study of Al-Zaubi (2013), Awawda (2015) in design the study tool, and the questionnaire consisted in its initial form of (51) paragraphs and five fields, and after verification by the arbitrators, it became in its final form (50) paragraphs and five fields, namely the paper and pen evaluation strategy, the performance-based evaluation strategy, observation evaluation strategy, self-review evaluation strategy, and communication evaluation strategy, to be able to reach answers to the study questions.

2.2.1: Validation of the study tool:

The authenticity of the tool presented in its initial form has been verified by (11) referees who are service owners in curricula and teaching methods, in addition to supervisors and specialists in the field, to express their views on it, to ensure that it measures what it is designed for, and to ensure the comprehensiveness of the measurement items, the opinions of the respondents about the degree of use of realistic evaluation, the sufficiency of the paragraphs, to cover all activities that need to be measured in the field of using realistic evaluation, and the belonging of each paragraph to its field, so that each paragraph is in the field to be measured, and the sequence and clarity of paragraphs.

After the arbitrators gave their opinions and commented on them, it was reformulated again, as a number of new paragraphs were built and others were deleted due to lack of clarity or repetition, and some paragraphs were reformulated, and thus the tool became valid for measuring what is intended to be measured. Three paragraphs have been deleted in Domains One, Two and Four, and two paragraphs have been amended in domains three and five.

The validity of the instrument was verified by calculating the correlation coefficient (Pearson) for each paragraph in the domain and then calculate the significance level for each paragraph.

Table 2 shows the values of the correlation coefficients (Pearson correlation) and the level of significance for correlation items and the degree of use of realistic evaluation among primary school teachers in international schools. 
Table 2: Correlation Coefficient (Pearson correlation) and the level of significance.

\begin{tabular}{|c|c|c|c|c|}
\hline Strategy & $\begin{array}{l}\text { Paragraph } \\
\text { No. }\end{array}$ & The paragraphs & $\begin{array}{l}\text { Correlation } \\
\text { Coefficient }\end{array}$ & $\begin{array}{l}\text { Level of } \\
\text { significance }\end{array}$ \\
\hline \multirow{10}{*}{ 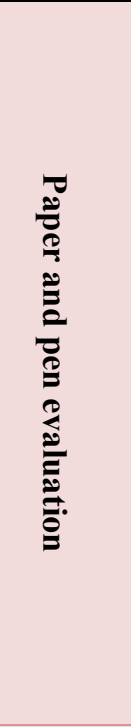 } & 1 & $\begin{array}{l}\text { Prepare the final evaluation according to the } \\
\text { elements of the test paper }\end{array}$ & 0.80 & $<0.001$ \\
\hline & 2 & Clearly define the purpose of the evaluation & 0.50 & 0.02 \\
\hline & 3 & $\begin{array}{l}\text { Follow the guidelines for preparing the different } \\
\text { question types }\end{array}$ & 0.72 & $<0.001$ \\
\hline & 4 & $\begin{array}{l}\text { Determine the special products required of the } \\
\text { student }\end{array}$ & 0.77 & $<0.001$ \\
\hline & 5 & $\begin{array}{l}\text { Analyze the content of the book into main and sub- } \\
\text { topics }\end{array}$ & 0.88 & $<0.001$ \\
\hline & 6 & $\begin{array}{l}\text { Interpret the test results to identify individual } \\
\text { differences between students }\end{array}$ & 0.87 & $<0.001$ \\
\hline & 7 & I lay out the questions based on a specification chart & 0.83 & $<0.001$ \\
\hline & 8 & $\begin{array}{l}\text { Use appropriate statistical indicators to analyze the } \\
\text { evaluation }\end{array}$ & 0.74 & $<0.001$ \\
\hline & 9 & I correct the questions accurately and objectively & 0.80 & $<0.001$ \\
\hline & 10 & $\begin{array}{l}\text { I mark questions according to the requirements of } \\
\text { each question }\end{array}$ & 0.70 & $<0.001$ \\
\hline \multirow{10}{*}{ 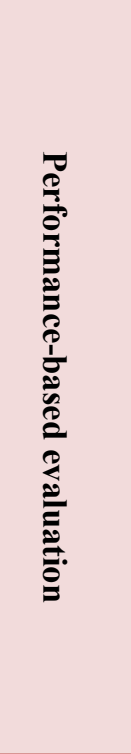 } & 11 & Clearly define the purpose of the evaluation & 0.85 & $<0.001$ \\
\hline & 12 & $\begin{array}{l}\text { I provide the student with feedback after } \\
\text { implementing the evaluation }\end{array}$ & 0.77 & $<0.001$ \\
\hline & 13 & $\begin{array}{l}\text { Determine the behavioral knowledge and skills to be } \\
\text { measured }\end{array}$ & 0.50 & $\mathbf{0 . 0 3}$ \\
\hline & 14 & $\begin{array}{l}\text { I am interested in the student's participation with } \\
\text { practical demonstrations (simulation, role-playing) }\end{array}$ & 0.68 & $<\mathbf{0 . 0 0 1}$ \\
\hline & 15 & $\begin{array}{l}\text { Determine the special results to be demonstrated by } \\
\text { the student }\end{array}$ & 0.66 & $<0.001$ \\
\hline & 16 & $\begin{array}{l}\text { Execute the evaluation according to the preset } \\
\text { schedule }\end{array}$ & 0.88 & $<0.001$ \\
\hline & 17 & $\begin{array}{l}\text { I assist the student in obtaining the necessary } \\
\text { equipment for him to do something }\end{array}$ & 0.73 & $<0.001$ \\
\hline & 18 & $\begin{array}{l}\text { Choosing the appropriate methods for measuring } \\
\text { skills (cross-list. Ladder of appreciation) }\end{array}$ & 0.65 & $<0.001$ \\
\hline & 19 & $\begin{array}{l}\text { I encourage students to use skills and knowledge in } \\
\text { practical life }\end{array}$ & 0.78 & $<0.001$ \\
\hline & 20 & I observe students while they do errands & 0.79 & $<0.001$ \\
\hline \multirow{10}{*}{ 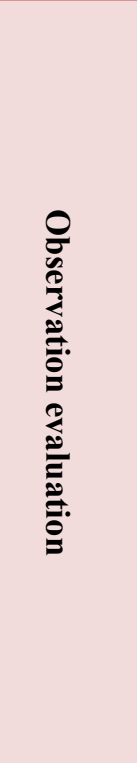 } & 21 & Define the learning outcomes to be observed & 0.80 & $<0.001$ \\
\hline & 22 & Determine the goal of the student's observation & 0.81 & $<0.001$ \\
\hline & 23 & Use automatic note during evaluation & 0.69 & $<0.001$ \\
\hline & 24 & $\begin{array}{l}\text { I evaluate my students' performance using structured } \\
\text { note }\end{array}$ & 0.46 & 0.04 \\
\hline & 25 & $\begin{array}{l}\text { Identify the practices, tasks required, and } \\
\text { performance indicators }\end{array}$ & 0.70 & $<0.001$ \\
\hline & 26 & $\begin{array}{l}\text { Arrange the required practices, tasks, and } \\
\text { performance indicators in a logical sequence }\end{array}$ & 0.82 & $<0.001$ \\
\hline & 27 & $\begin{array}{l}\text { Design tool for recording practices, tasks and } \\
\text { performance indicators such as rating scale and } \\
\text { write-off lists }\end{array}$ & 0.67 & $<0.001$ \\
\hline & 28 & $\begin{array}{l}\text { Repeat the note to ensure consistent student } \\
\text { performance }\end{array}$ & 0.77 & $<0.001$ \\
\hline & 29 & $\begin{array}{l}\text { Take notes on the student while doing work in the } \\
\text { lab }\end{array}$ & 0.56 & 0.01 \\
\hline & 30 & $\begin{array}{l}\text { I write down the results of the observations without } \\
\text { influencing my personal opinion }\end{array}$ & 0.64 & $<0.001$ \\
\hline
\end{tabular}




\begin{tabular}{|c|c|c|c|c|}
\hline Strategy & $\begin{array}{l}\text { Paragraph } \\
\text { No. }\end{array}$ & The paragraphs & $\begin{array}{l}\text { Correlation } \\
\text { Coefficient }\end{array}$ & $\begin{array}{l}\text { Level of } \\
\text { significance }\end{array}$ \\
\hline \multirow{10}{*}{ 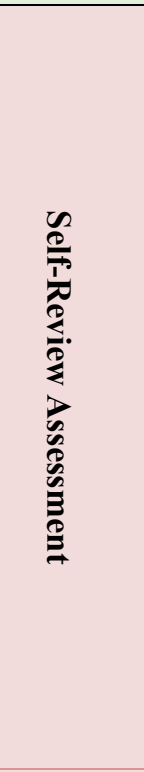 } & 31 & $\begin{array}{l}\text { The purpose of the self-review evaluation is clearly } \\
\text { defined }\end{array}$ & 0.45 & 0.04 \\
\hline & 32 & $\begin{array}{l}\text { I use various forms of self-evaluation, such as } \\
\text { conferences, face-to-face interviews ... etc. }\end{array}$ & 0.51 & 0.02 \\
\hline & 33 & Motivate students to do the self-evaluation process & 0.51 & 0.02 \\
\hline & 34 & Explain how to use self-correcting tools & 0.79 & $<0.001$ \\
\hline & 35 & I develop these tools in collaboration with students & 0.77 & $<0.001$ \\
\hline & 36 & $\begin{array}{l}\text { I help students to find questions about self- } \\
\text { evaluation of their work }\end{array}$ & 0.82 & $<0.001$ \\
\hline & 37 & $\begin{array}{l}\text { Monitor the extent to which students practice their } \\
\text { self-evaluation }\end{array}$ & 0.68 & $<0.001$ \\
\hline & 38 & $\begin{array}{l}\text { I encourage the students to discover and address } \\
\text { their deficiencies }\end{array}$ & 0.58 & 0.01 \\
\hline & 39 & $\begin{array}{l}\text { I help students develop the self-ability to analyze } \\
\text { their performance and judge it by clear standards }\end{array}$ & 0.58 & 0.01 \\
\hline & 40 & $\begin{array}{l}\text { Students are encouraged to compare their current } \\
\text { self-assessment results with previous results }\end{array}$ & 0.71 & $<0.001$ \\
\hline \multirow{10}{*}{ 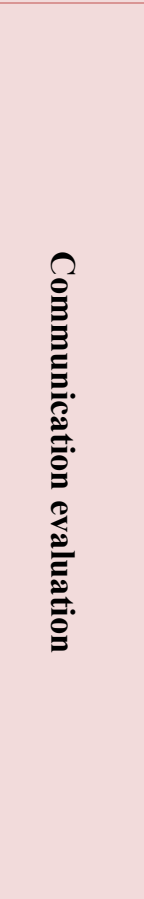 } & 41 & $\begin{array}{l}\text { Identify communication methods and strategies such } \\
\text { as mini conferences, and small groups ....... }\end{array}$ & 0.79 & $<0.001$ \\
\hline & 42 & $\begin{array}{l}\text { I encourage students to work in small groups to } \\
\text { solve scientific problems }\end{array}$ & 0.76 & $<0.001$ \\
\hline & 43 & $\begin{array}{l}\text { I communicate with students in a mini conference to } \\
\text { show their performance }\end{array}$ & 0.91 & $<0.001$ \\
\hline & 44 & $\begin{array}{l}\text { I encourage the student to evaluate the activities of } \\
\text { his classmates }\end{array}$ & 0.88 & $<0.001$ \\
\hline & 45 & $\begin{array}{l}\text { I encourage students to accept critical evaluation of } \\
\text { their work from their classmates }\end{array}$ & 0.82 & $<0.001$ \\
\hline & 46 & $\begin{array}{l}\text { Use the interview strategy to assess students' } \\
\text { thinking process and their study problems }\end{array}$ & 0.75 & $<0.001$ \\
\hline & 47 & $\begin{array}{l}\text { I measure student performance through a question- } \\
\text { and-answer strategy }\end{array}$ & 0.69 & $<0.001$ \\
\hline & 48 & $\begin{array}{l}\text { Set dates for meetings with students who are } \\
\text { programmed to evaluate their progress in the project } \\
\text { and ways to improve it }\end{array}$ & 0.63 & $<0.001$ \\
\hline & 49 & $\begin{array}{l}\text { I collect information about student progress on a } \\
\text { project using multiple communication methods }\end{array}$ & 0.63 & $<0.001$ \\
\hline & 50 & $\begin{array}{l}\text { I encourage students to solve problems with social } \\
\text { contact }\end{array}$ & 0.65 & $<0.001$ \\
\hline
\end{tabular}

All values of the correlation coefficients for the paragraphs were high and statistically significant at $(\alpha=$ $0.05)$. The results of the correlation coefficient ranged between $(0.45-0.91)$. Therefore, the data presented in the previous table indicate that all the values of the paragraph's correlation coefficients in the first domain (the paper-and-pencil strategy) were high and statistically significant at $(\alpha=0.05)$, and the results of the correlation coefficient ranged between $(0.50-0.88)$ and this enhances the validity of the internal consistency of the paragraphs of the first field, and all the values of the paragraphs correlation coefficients in the second domain (performance-based evaluation strategy)were high and statistically significant at $(\alpha=0.05)$, and the results of the correlation coefficient ranged between $(0.50-0.88)$, and this enhances the validity of the internal consistency of the paragraphs of the second field, and the data in the table indicate that all the values of the paragraphs correlation coefficients in the third domain,(the observational strategy) were high and statistically significant at $(\alpha=0.05)$, and the results of the correlation coefficient ranged between $(0.46-0.82)$ and this enhances the validity of the internal consistency of the paragraphs of the third field, and the data in the table indicate that all the values of the paragraphs correlation coefficients in the fourth domain (self-evaluation strategy) were high and statistically significant at $(\alpha=0.05)$, and the results of the correlation coefficient ranged between $(0.45-0.82)$, and this enhances the validity of the internal consistency of the paragraphs of the fourth field, and the data in the 
table indicate that all values of the paragraphs correlation coefficients in the fifth domain (communication evaluation strategy) were high and statistically significant at $(\alpha=0.05)$, and the results of the correlation coefficient ranged between $(0.63-0.91)$, and this enhances the validity of the internal .consistency of the paragraphs of the fifth field.

To calculate the correlation values between the five domains and the overall tool, the matrix shown in Table 3 was used.

Table 3: Matrix of correlation coefficients between the fields of study and the overall tool.

\begin{tabular}{|l|l|l|l|l|l|l|}
\hline Strategy & $\begin{array}{l}\text { Paper and } \\
\text { pen } \\
\text { evaluation }\end{array}$ & $\begin{array}{l}\text { evaluation } \\
\text { evaluance-based }\end{array}$ & $\begin{array}{l}\text { Observation } \\
\text { evaluation }\end{array}$ & $\begin{array}{l}\text { Self-Review } \\
\text { Assessment }\end{array}$ & $\begin{array}{l}\text { Communication } \\
\text { evaluation }\end{array}$ & $\begin{array}{l}\text { The } \\
\text { overall } \\
\text { tool }\end{array}$ \\
\hline Paper and pen evaluation & 1 & $0.86^{* *}$ & $0.90^{* *}$ & $0.55^{* *}$ & $0.53^{* *}$ & $0.89^{* *}$ \\
\hline $\begin{array}{l}\text { Performance-based } \\
\text { evaluation }\end{array}$ & & 1 & $0.85^{* *}$ & $0.87^{* *}$ & $0.56^{* *}$ & $0.83^{* *}$ \\
\hline Observation evaluation & & & 1 & $0.57^{* *}$ & $0.60^{* *}$ & $0.90^{* *}$ \\
\hline Self-Review Assessment & & & & 1 & $0.90^{* *}$ & $0.81^{* *}$ \\
\hline Communication evaluation & & & & & 1 & $0.64^{* *}$ \\
\hline The overall tool & & & & & & 1 \\
\hline
\end{tabular}

** $(a=0.05)$. It is noted that all the values of the correlation coefficients are high and statistically significant at the level of significance $(\mathrm{a}=0.05)$ The correlation coefficients ranged between $(0.53-0.90)$, which enhances the validity of the internal consistency of the study tool.

2.2.2: Tool stability:

The stability of the tool was verified by applying it to a pilot sample of 30 male and female teachers from outside the study sample. The reliability coefficient was calculated by two methods: internal consistency and half fraction method. The Cronbach Alpha equation was used (Cronbach's alpha) to measure the degree of internal consistency of the paragraphs of the resolution, and the results were as in Table 4:

Table 4: Internal consistency factor using Cronbach-alpha and the half fraction: stability factor of the study tool

\begin{tabular}{|l|l|l|l|}
\hline Field & Cronbach alpha & Half Fraction & No. of Paragraphs \\
\hline Paper and pen evaluation & 0.91 & 0.90 & $\mathbf{1 0}$ \\
\hline Performance-based evaluation & 0.90 & 0.81 & $\mathbf{1 0}$ \\
\hline Observation evaluation & 0.87 & 0.84 & $\mathbf{1 0}$ \\
\hline Self-Review Assessment & 0.83 & 0.75 & $\mathbf{1 0}$ \\
\hline Communication evaluation & 0.89 & 0.90 & $\mathbf{1 0}$ \\
\hline The total tool & $\mathbf{0 . 9 5}$ & $\mathbf{0 . 9 2}$ & $\mathbf{5 0}$ \\
\hline
\end{tabular}

The above table shows the values of the stability coefficients according to the Cronbach alpha and half fraction methods, where the value of the internal consistency of the total tool was (Cronbach alpha $=0.95)$ and the value of the internal consistency coefficients for fields using Cronbach alpha ranged between $(0.83-0.91)$, while the value of the half fraction for the total tool was (0.92), and the value of field coefficients using half fraction ranged between $(0.75-0.90)$. It is noted that there are high stability coefficients values. This enhances the accuracy of the study tool and its suitability for application.

\section{3: Study variables:}

The study variables included the following variables: Primary variables include years of service and it has three levels (less than 5 years, 5 -10 years, 10 years and more), the gender is divided into two categories (male and female) and academic qualification (specialization) and has two categories (humanitarian and scientific). Secondary variable: The degree of use of international school teachers in the upper elementary stage for realistic evaluation.

\section{4: Study procedures:}

The current study adopted the current procedures

- A review of the relevant theoretical literature.

- Study tool development.

- Determine the study community that consists of teachers of the higher basic stage in international schools in the Aljama 'a district.

- Finding the validity and reliability of the tool

- Application of questionnaires to the identified sample

- Statistical treatment of the data collected from the study sample

- To answer the first question of the study and its text: To what degree do international school teachers use realistic assessment in the upper elementary stage? Mean values and standard deviations were calculated. 
- To answer the second question of the study and its text: Does the degree to which international school teachers use realistic assessments in the upper elementary stage differ according to gender, years of service or the interaction between them? Mean values and standard deviations were calculated, and the Two-Way ANOVA test was used to examine the hypothesis related to gender and years of service.

- To answer the third question of the study and its text: Does the degree to which international school teachers use realistic assessment in the upper elementary stage differ according to the academic specialization? The t-tests were used to examine the hypothesis according to academic specialization.

- Review and discuss results

- Provide recommendations and suggestions based on the results reached

Statistics in this study was performed using SPSS and conducting appropriate statistical analyzes to reach the results, and to determine the degree of response means of the study sample, the weight scale was adopted as in Table 5:

Table 5: Scale for evaluation degree

\begin{tabular}{|l|l|}
\hline Scale & Evaluation \\
\hline $1.00-1.80$ & Very low \\
\hline $1.81-2.60$ & low \\
\hline $2.61-3.40$ & Medium \\
\hline $3.41-4.20$ & High \\
\hline $4.21-5.00$ & Very high \\
\hline
\end{tabular}

The following statistical tests were used

- Cronbach alpha test (Cronbach Alpha) and half fraction to measure instrument stability.

- Correlation matrix to measure of central tendency and the measure of dispersion).

- Arithmetic means and standard deviation (to answer the study questions).

\section{Results}

To answer the study's first question: The values of the arithmetic mean and the standard deviations were calculated as shown in Table 6:

Table 6: The arithmetic means and standard deviations of the responses of the study sample individuals to the paragraphs related to all fields of the realistic evaluation arranged in descending order.

\begin{tabular}{|c|c|c|c|c|c|}
\hline \multicolumn{6}{|c|}{ Statistical connotations } \\
\hline \multicolumn{2}{|c|}{ RankParagraph no. } & The paragraphs & Mean & $\mathrm{SD}$ & Degree \\
\hline 1 & 6 & $\begin{array}{l}\text { Interpret the test results to identify individual differences between } \\
\text { students }\end{array}$ & 4.27 & 0.8 & $\begin{array}{l}\text { Very } \\
\text { large }\end{array}$ \\
\hline 2 & 9 & I correct the questions accurately and objectively & 4.16 & 0.91 & Large \\
\hline 3 & 7 & I lay out questions based on a specification chart & 4.1 & 0.85 & Large \\
\hline 4 & 8 & Use appropriate statistical indicators to analyze the evaluation & 4.09 & 1.01 & Large \\
\hline 5 & 3 & Follow the guidelines for preparing the different question types & 4.03 & 1.16 & Large \\
\hline 6 & 5 & Analyze the content of the book into main and sub-topics & 3.96 & 1.06 & Large \\
\hline 7 & 10 & I mark questions according to the requirements of each question & 3.94 & 0.94 & Large \\
\hline 8 & 1 & Prepare the final evaluation according to the elements of the test paper & 3.83 & 1.1 & Large \\
\hline 9 & 2 & Clearly define the purpose of the evaluation & 3.72 & 1.25 & Large \\
\hline 10 & 4 & Determine the special products required of the student & 2.74 & 1.55 & Medium \\
\hline & & First domain Total & 3.88 & 0.77 & Large \\
\hline 11 & 18 & $\begin{array}{l}\text { Choosing the appropriate methods for measuring skills (cross-list. } \\
\text { Ladder of appreciation) }\end{array}$ & 4.07 & 0.83 & Large \\
\hline 12 & 11 & Clearly define the purpose of the evaluation & 4.00 & 1.01 & Large \\
\hline 13 & 20 & I observe students while they do errands & 3.96 & 0.96 & Large \\
\hline 14 & 17 & $\begin{array}{l}\text { I assist the student in obtaining the necessary equipment for him to do } \\
\text { something }\end{array}$ & 3.95 & 0.85 & Large \\
\hline 15 & 13 & Determine the behavioral knowledge and skills to be measured & 3.92 & 0.86 & Large \\
\hline 16 & 14 & $\begin{array}{l}\text { I am interested in the student's participation with practical } \\
\text { demonstrations (simulation, role- playing) }\end{array}$ & 3.92 & 0.92 & Large \\
\hline 17 & 16 & Execute the evaluation according to the preset schedule & 3.92 & 0.87 & Large \\
\hline 18 & 19 & I encourage students to use skills and knowledge in practical life & 3.87 & 1.01 & Large \\
\hline 19 & 15 & Determine the special results to be demonstrated by the student & 3.83 & 1.00 & Large \\
\hline 20 & 12 & $\begin{array}{l}\text { I provide the student with feedback after the implementation of the } \\
\text { evaluation }\end{array}$ & 3.82 & 1.08 & Large \\
\hline
\end{tabular}




\begin{tabular}{|c|c|c|c|c|c|}
\hline & & Second domain Total & 3.92 & 0.72 & Large \\
\hline 21 & 21 & Define the learning outcomes to be observed & 4.22 & 0.83 & $\begin{array}{l}\text { Very } \\
\text { large }\end{array}$ \\
\hline 22 & 26 & $\begin{array}{l}\text { Arrange the required practices, tasks and performance indicators in a } \\
\text { logical sequence }\end{array}$ & 4.09 & 1.18 & Large \\
\hline 23 & 30 & $\begin{array}{l}\text { I write down the results of the observations without affecting my } \\
\text { personal opinion }\end{array}$ & 4 & 1.22 & Large \\
\hline 24 & 23 & Use automatic note during evaluation & 3.93 & 1.09 & Large \\
\hline 25 & 24 & I evaluate my students' performance using structured note & 3.93 & 1.14 & Large \\
\hline 26 & 28 & Repeat the note to ensure consistent student performance & 3.93 & 1.12 & Large \\
\hline 27 & 22 & Determine the goal of the student's note & 3.92 & 0.91 & Large \\
\hline 28 & 29 & Take notes about the student while doing work in the lab & 3.86 & 1.06 & Large \\
\hline 29 & 25 & Identify the practices, tasks required and performance indicators & 3.85 & 1.1 & Large \\
\hline \multirow[t]{2}{*}{30} & 27 & $\begin{array}{l}\text { Design tool for recording practices tasks and performance indicators } \\
\text { such as scale and write-off lists }\end{array}$ & 3.82 & 1.13 & Large \\
\hline & & Third domain Total & 3.95 & 0.86 & Large \\
\hline 31 & 38 & I encourage the students to discover and address their deficiencies & 4.43 & 0.68 & $\begin{array}{l}\text { Very } \\
\text { large }\end{array}$ \\
\hline 32 & 40 & $\begin{array}{l}\text { Students are encouraged to compare their current self-assessment results } \\
\text { with previous results }\end{array}$ & 4.38 & 0.72 & $\begin{array}{l}\text { Very } \\
\text { large }\end{array}$ \\
\hline 33 & 39 & $\begin{array}{l}\text { I help students develop the self-ability to observe, analyze and judge } \\
\text { their performance by clear standards }\end{array}$ & 4.26 & 0.97 & $\begin{array}{l}\text { Very } \\
\text { large }\end{array}$ \\
\hline 34 & 34 & Explain how to use the self-correcting tools & 4.23 & 0.91 & $\begin{array}{l}\text { Very } \\
\text { large }\end{array}$ \\
\hline 35 & 37 & Monitor the extent to which students practice their self-evaluation & 4.09 & 1.04 & big \\
\hline 36 & 31 & The purpose of the self-review evaluation is clearly defined & 3.93 & 1 & big \\
\hline 37 & 35 & I develop these tools in collaboration with students & 3.91 & 0.95 & big \\
\hline 38 & 36 & I help students to find questions about the self-evaluation of their work & 3.77 & 1.14 & big \\
\hline 39 & 33 & Motivate students to do the self-evaluation process & 3.74 & 1.11 & big \\
\hline \multirow[t]{2}{*}{40} & 32 & $\begin{array}{l}\text { I use various forms of self-evaluation such as conferences, face to face } \\
\text { interviews... etc. }\end{array}$ & 3.61 & 1.35 & big \\
\hline & & Fourth domain Total & 4.04 & 0.66 & big \\
\hline 41 & 41 & $\begin{array}{l}\text { Identify communication methods and strategies such mini- conference } \\
\text { and small groups }\end{array}$ & 4.52 & 0.65 & $\begin{array}{l}\text { Very } \\
\text { large }\end{array}$ \\
\hline 42 & 46 & $\begin{array}{l}\text { Use the interview strategy to assess students' thinking process and their } \\
\text { study problems }\end{array}$ & 4.51 & 0.69 & $\begin{array}{l}\text { Very } \\
\text { large }\end{array}$ \\
\hline 43 & 47 & I measure student performance through a question-and-answer strategy & 4.39 & 0.87 & $\begin{array}{l}\text { Very } \\
\text { large }\end{array}$ \\
\hline 44 & 43 & $\begin{array}{l}\text { I communicate with students in a mini conference to show their } \\
\text { performance }\end{array}$ & 4.38 & 2.74 & $\begin{array}{l}\text { Very } \\
\text { large }\end{array}$ \\
\hline 45 & 45 & $\begin{array}{l}\text { I encourage students to accept critical evaluation of their work from } \\
\text { their classmates }\end{array}$ & 4.3 & 0.79 & $\begin{array}{l}\text { Very } \\
\text { large }\end{array}$ \\
\hline 46 & 42 & $\begin{array}{l}\text { I encourage students to work in small groups to solve scientific } \\
\text { problems }\end{array}$ & 4.22 & 0.98 & $\begin{array}{l}\text { Very } \\
\text { large }\end{array}$ \\
\hline 47 & 44 & Encourage the student to evaluate the activities of his classmates & 4.12 & 0.95 & Large \\
\hline 48 & 48 & $\begin{array}{l}\text { Set dates for meetings with students who are programmed to evaluate } \\
\text { their progress in the project and ways to improve it }\end{array}$ & 4.04 & 0.95 & Large \\
\hline 49 & 49 & $\begin{array}{l}\text { I collect information about student progress on a project using multiple } \\
\text { communication methods }\end{array}$ & 3.5 & 1.23 & Large \\
\hline \multirow[t]{3}{*}{50} & 50 & I encourage students to solve problems with social contact & 3.25 & 1.33 & Medium \\
\hline & & Fifth domain Total & 4.12 & 0.05 & Large \\
\hline & & Total & 3.98 & 0.63 & Large \\
\hline
\end{tabular}

It is noted that the degree of use of realistic evaluation for teachers of the higher basic stage in international schools is large (arithmetic mean $=3.98$ ), and the arithmetic means ranged between (3.88-4.12). The degree of use of the fifth domain (the communication evaluation strategy)was large (arithmetic mean $=4.12$ ), and the arithmetic means of the paragraphs ranged between (3.25 - 4.52) and it was the highest among the domains, followed in the second place by the degree of use of the fourth domain (the self-review evaluation strategy) and 
it was large (arithmetic mean= 4.04) and arithmetic means for the paragraphs ranged between (3.61-4.43), then in the third place the degree of use of the third domain (observation evaluation strategy) and it was large (arithmetic mean $=3.95$ (, and the arithmetic means of the items ranged between (3.82-4.22). The degree of use of the second domain (performance-based evaluation strategy) came in fourth place (arithmetic mean $=3$ ).

The first field ranked paragraph No. 6 first with a very large degree (Interpret the test results to identify individual differences between students) with (arithmetic mean $=4.27$ ), followed by paragraph No. 9 (I correct the questions accurately and objectively) in second place with a large degree (arithmetic mean $=4.16$ ), then paragraph No. 2 was ranked before last to a large degree (arithmetic mean $=3.72$ ), and paragraph No. 4 (Determine the special products required of the student) came last with a mean degree (arithmetic mean $=2.74$ ).

The second field showed that paragraph No.18 (choosing appropriate methods for measuring skills: crosslist, ladder of appreciation) was in the first place with a large degree (arithmetic mean=4.07), followed by paragraph No. 11 (Clearly define the purpose of the evaluation) ranked second to a large degree (the arithmetic mean $=4.00$ ), and paragraph No. 15 (Determine the special results to be demonstrated by the student) was ranked before last to a large extent (arithmetic mean $=3.83$ ), and paragraph No. 12 (I provide the student with feedback after the implementation of the evaluation( came in the last rank (the arithmetic mean $=3.82$ ).

The third field showed that paragraph No. 21 (Define the learning outcomes to be observed) was in the first place to a very large degree (arithmetic mean $=4.22$ ), followed by paragraph No. 26 (arrange the required practices, tasks required and performance indicators in a logical sequence) ranked second to a very large degree (arithmetic mean paragraph $=4.09$ ), then paragraph No. 25 (Identify the practices, tasks required and performance indicators) ranked second to last to a large extent (arithmetic mean=3.85), and paragraph No. 27 (design tool for recording practices, tasks and performance indicators such as the rating scale and write-off lists) ranked last to a large extent (arithmetic mean $=3.82$ ).

The fourth field showed that paragraph No. 38 (I encourage students to discover and address their deficiencies), ranked first to a very large degree (arithmetic mean $=4.43$ ), followed by paragraph No. 40 (Students are encouraged to compare their current self-assessment results with previous results) in second place with a very large degree (arithmetic mean $=4.38$ ), and paragraph No. 33 (Motivate students to do the selfevaluation process) was ranked next to last to a large extent (arithmetic mean $=3.72$ ), and paragraph No. 32 (I use various forms of self-evaluation, such as conferences, face to face interviews) ranked last to a large extent (arithmetic mean=3.61).

The fifth field showed that paragraph No. 41 (Identify communication methods and strategies such miniconference and small groups) came in first place with a very large degree (arithmetic mean $=4.52$ ), followed by paragraph No. 46 (Use the interview strategy to assess students' thinking process and their study) ranked second in a very large degree (arithmetic mean $=4.51$ ), and paragraph No. 49 (I collect information on the progress of students in a specific project through multiple communication methods) was ranked before last to a large degree (arithmetic mean $=3.5$ ), and paragraph No 50 came last (I encourage students to solve problems with social communication) with a medium degree (arithmetic mean $=3.25$ )

To answer the second question: The arithmetic means and standard deviations were calculated and using multiple binary variance analysis as shown in Table 7.

Table 7: Values of arithmetic means and standard deviations according to gender and years of service variables.

\begin{tabular}{|c|c|c|c|c|c|}
\hline \multicolumn{6}{|c|}{ Statistical connotations } \\
\hline Field & Gender & Years of service & Number & Arithmetic means & $\mathrm{SD}$ \\
\hline \multirow{12}{*}{ 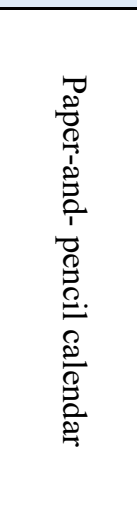 } & \multirow{4}{*}{ Males } & Less than 5 years & 38 & 3.80 & 0.67 \\
\hline & & From $5-10$ years & 44 & 3.88 & 0.82 \\
\hline & & More than 10 years & 48 & 3.82 & 0.67 \\
\hline & & Total & 130 & 3.84 & 0.72 \\
\hline & \multirow{4}{*}{ Females } & Less than 5 years & 73 & 3.89 & 0.80 \\
\hline & & From 5-10 years & 90 & 3.91 & 0.79 \\
\hline & & More than 10 years & 75 & 3.90 & 0.82 \\
\hline & & Total & 238 & 3.90 & 0.80 \\
\hline & \multirow{4}{*}{ Total } & Less than 5 years & 111 & 3.86 & 0.76 \\
\hline & & From 5-10 years & 134 & 3.90 & 0.80 \\
\hline & & More than 10 years & 123 & 3.87 & 0.76 \\
\hline & & Total & 368 & 3.88 & 0.77 \\
\hline \multirow{5}{*}{ 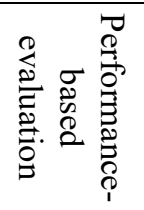 } & \multirow{4}{*}{ Males } & Less than 5 years & 38 & 3.91 & 0.65 \\
\hline & & From 5-10 years & 44 & 4.02 & 0.67 \\
\hline & & More than 10 years & 48 & 3.92 & 0.59 \\
\hline & & Total & 130 & 3.95 & 0.63 \\
\hline & & Less than 5 years & 73 & 3.89 & 0.76 \\
\hline
\end{tabular}




\begin{tabular}{|c|c|c|c|c|c|}
\hline & \multirow{3}{*}{ Females } & From $5-10$ years & 90 & 3.99 & 0.74 \\
\hline & & More than 10 years & 75 & 3.83 & 0.78 \\
\hline & & Total & 238 & 3.91 & 0.76 \\
\hline & \multirow{4}{*}{ Total } & Less than 5 years & 111 & 3.90 & 0.72 \\
\hline & & From 5-10 years & 134 & 4.00 & 0.72 \\
\hline & & More than 10 years & 123 & 3.86 & 0.71 \\
\hline & & Total & 368 & 3.92 & 0.72 \\
\hline \multirow{12}{*}{ 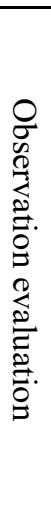 } & \multirow{4}{*}{ Males } & Less than 5 years & 38 & 3.56 & \\
\hline & & From 5-10 years & 44 & 3.73 & 0.98 \\
\hline & & More than 10 years & 48 & 3.84 & 0.80 \\
\hline & & Total & 130 & 3.72 & 0.92 \\
\hline & & Less than 5 years & 73 & 4.15 & 0.72 \\
\hline & & From 5-10 years & 90 & 4.04 & 0.86 \\
\hline & Females & More than 10 years & 75 & 4.06 & 0.82 \\
\hline & & Total & 238 & 4.08 & 0.80 \\
\hline & & Less than 5 years & 111 & 3.95 & 0.86 \\
\hline & & From 5-10 years & 134 & 3.94 & 0.91 \\
\hline & Total & More than 10 years & 123 & 3.97 & 0.81 \\
\hline & & Total & 368 & 3.95 & 0.86 \\
\hline & & Less than 5 years & 38 & 3.71 & 0.72 \\
\hline & & From 5-10 years & 44 & 3.90 & 0.65 \\
\hline & Males & More than 10 years & 48 & 3.80 & 0.71 \\
\hline$\stackrel{0}{5}$ & & Total & 130 & 3.81 & 0.69 \\
\hline$\stackrel{\vec{Q}}{\leq}$ & & Less than 5 years & 73 & 4.21 & 0.64 \\
\hline$\stackrel{0}{*}$ & & From 5-10 years & 90 & 4.13 & 0.57 \\
\hline 8 & Females & More than 10 years & 75 & 4.16 & 0.63 \\
\hline$\stackrel{0}{\Xi}$ & & Total & 238 & 4.16 & 0.61 \\
\hline 营. & & Less than 5 years & 111 & 4.04 & 0.71 \\
\hline$\overline{0}$ & Total & From 5-10 years & 134 & 4.05 & 0.61 \\
\hline & & More than 10 years & 123 & 4.01 & 0.69 \\
\hline & & Total & 368 & 4.04 & 0.66 \\
\hline & & Less than 5 years & 38 & 38.50 & 6.52 \\
\hline & & From 5-10 years & 44 & 41.18 & 9.79 \\
\hline$\overbrace{}^{2}$ & Males & More than 10 years & 48 & 38.43 & 6.45 \\
\hline 志 & & Total & 130 & 39.38 & 7.81 \\
\hline$E$. & & Less than 5 years & 73 & 42.61 & 6.26 \\
\hline §. & & From 5-10 years & 90 & 42.26 & 6.14 \\
\hline 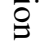 & Females & More than 10 years & 75 & 42.08 & 6.81 \\
\hline 2 & & Total & 238 & 42.31 & 6.38 \\
\hline$\stackrel{2}{\Xi}$ & & Less than 5 years & 111 & 41.20 & 6.62 \\
\hline$\stackrel{2}{0}$. & & From 5-10 years & 134 & 41.91 & 7.52 \\
\hline & Total & More than 10 years & 123 & 40.65 & 6.88 \\
\hline & & Total & 368 & 41.27 & 7.05 \\
\hline & & Less than 5 years & 38 & 3.77 & 0.64 \\
\hline & & From 5-10 years & 44 & 3.93 & 0.63 \\
\hline & Males & More than 10 years & 48 & 3.84 & 0.59 \\
\hline & & Total & 130 & 3.85 & 0.62 \\
\hline & & Less than 5 years & 73 & 4.08 & 0.63 \\
\hline-1 & & From 5-10 years & 90 & 4.06 & 0.59 \\
\hline$\vec{D}$ & Females & More than 10 years & 75 & 4.03 & 0.68 \\
\hline & & Total & 238 & 4.06 & 0.63 \\
\hline & & Less than 5 years & 111 & 3.97 & 0.65 \\
\hline & & From 5-10 years & 134 & 4.01 & 0.60 \\
\hline & Total & More than 10 years & 123 & 3.96 & 0.65 \\
\hline & & Total & 368 & 3.98 & 0.63 \\
\hline
\end{tabular}

It is noted from the table that there are apparent differences between the two variables (gender and years of 
service) in favor of females, and to find these differences, the multiple binary variance analysis of the two variables of gender and years of service was calculated as shown in Table 8:

Table 8: Results of multiple binary variance analysis of gender variables and years of service.

\section{Tests of effects between subjects}

\begin{tabular}{|c|c|c|c|c|c|c|}
\hline Variable & Dependent variable & $\begin{array}{l}\text { Sum of } \\
\text { squares }\end{array}$ & $\begin{array}{l}\text { Degree of } \\
\text { freedom }\end{array}$ & $\begin{array}{l}\text { Means of } \\
\text { squares }\end{array}$ & $\begin{array}{l}\text { F } \\
\text { value } \\
\end{array}$ & $\begin{array}{l}\text { significance level } \\
\text { (a) }\end{array}$ \\
\hline \multirow[t]{6}{*}{ Gender } & $\begin{array}{l}\text { Paper and pen } \\
\text { evaluation }\end{array}$ & 0.38 & 1 & 0.38 & 0.62 & 0.43 \\
\hline & $\begin{array}{l}\text { Performance-based } \\
\text { evaluation }\end{array}$ & 0.17 & 1 & 0.17 & 0.32 & 0.56 \\
\hline & Observation evaluation & 11.70 & 1 & 11.70 & 16.17 & 0.00 \\
\hline & Self-Review Assessment & 11.02 & 1 & 11.02 & 26.23 & 0.00 \\
\hline & $\begin{array}{l}\text { Communication } \\
\text { evaluation }\end{array}$ & 724.06 & 1 & 724.06 & 15.15 & 0.00 \\
\hline & Total & 3.71 & 1 & 3.71 & 9.33 & 0.00 \\
\hline \multirow{6}{*}{ Years of service } & $\begin{array}{l}\text { Paper and pen } \\
\text { evaluation }\end{array}$ & 0.13 & 2 & 0.06 & 0.11 & 0.89 \\
\hline & $\begin{array}{l}\text { Performance-based } \\
\text { evaluation }\end{array}$ & 1.06 & 2 & 0.53 & 1.01 & 0.36 \\
\hline & Observation evaluation & 0.48 & 2 & 0.24 & 0.33 & 0.71 \\
\hline & Self-Review Assessment & 0.14 & 2 & 0.07 & 0.17 & 0.84 \\
\hline & $\begin{array}{l}\text { Communication } \\
\text { evaluation }\end{array}$ & 139.71 & 2 & 69.85 & 1.46 & 0.23 \\
\hline & Total & 0.29 & 2 & 0.14 & 0.37 & 0.68 \\
\hline \multirow{6}{*}{$\begin{array}{l}\text { Gender }+ \text { Years of } \\
\text { Service }\end{array}$} & $\begin{array}{l}\text { Paper and pen } \\
\text { evaluation }\end{array}$ & 0.06 & 2 & 0.03 & 0.05 & 0.94 \\
\hline & $\begin{array}{l}\text { Performance-based } \\
\text { evaluation }\end{array}$ & 0.06 & 2 & 0.03 & 0.06 & 0.93 \\
\hline & Observation evaluation & 1.91 & 2 & 0.95 & 1.32 & 0.26 \\
\hline & Self-Review Assessment & 1.03 & 2 & 0.51 & 1.22 & 0.29 \\
\hline & $\begin{array}{l}\text { Communication } \\
\text { evaluation }\end{array}$ & 150.45 & 2 & 75.22 & 1.57 & 0.20 \\
\hline & Total & 0.48 & 2 & 0.24 & 0.60 & 0.54 \\
\hline \multirow{6}{*}{ Error coefficient } & $\begin{array}{l}\text { Paper and pen } \\
\text { evaluation }\end{array}$ & 221.38 & 362 & 0.61 & & \\
\hline & $\begin{array}{l}\text { Performance-based } \\
\text { evaluation }\end{array}$ & 189.86 & 362 & 0.52 & & \\
\hline & Observation evaluation & 261.92 & 362 & 0.72 & & \\
\hline & Self-Review Assessment & 152.08 & 362 & 0.42 & & \\
\hline & $\begin{array}{l}\text { Communication } \\
\text { evaluation }\end{array}$ & 17294.23 & 362 & 47.77 & & \\
\hline & Total & 143.94 & 362 & 0.39 & & \\
\hline \multirow{6}{*}{$\begin{array}{l}\text { Correction } \\
\text { coefficient }\end{array}$} & $\begin{array}{l}\text { Paper and pen } \\
\text { evaluation }\end{array}$ & 221.91 & 367 & & & \\
\hline & $\begin{array}{l}\text { Performance-based } \\
\text { evaluation }\end{array}$ & 191.33 & 367 & & & \\
\hline & Observation evaluation & 275.01 & 367 & & & \\
\hline & Self-Review Assessment & 163.82 & 367 & & & \\
\hline & $\begin{array}{l}\text { Communication } \\
\text { evaluation }\end{array}$ & 18242.71 & 367 & & & \\
\hline & Total & 148.19 & 367 & & & \\
\hline
\end{tabular}

The results showed that there are differences attributed to gender in favor of females in the overall tool (mean of squares $=3.71$ ) at the level of significance $a=0.05$, where the differences were clear in the third domain (observation evaluation strategy) mean of the squares was (11.07) at the level of significance $a=0.05$, and in the fourth domain (self-review evaluation strategy), where the mean of the squares was (11.02) at the level of significance $\mathrm{a}=0.05$, and at the fifth domain (communication evaluation strategy ) where the arithmetic mean of the squares(724.06) at the level of significance $(a=0.05)$, and there are no differences for years of 
service. There are no differences attributed to the interaction between gender and years of service.

To answer the third question: The arithmetic means and the standard deviation were calculated for two independent samples (humanitarian and scientific specialty). Parametric tests were used(t-Test) to investigate the differences between international school teacher's specialization and their use of realistic evaluation methods, as shown in Table 9.

Table 9: The statistical indications of two independent samples (humanitarian, scientific) and test results(t-Test) and its relationship to the fields of realistic evaluation strategy

\begin{tabular}{|l|l|l|l|l|l|l|l|l|}
\hline \multicolumn{9}{|c|}{ Statistical connotations } \\
\hline Field & Specialty & Number & Arithmetic means & Standard Error Mean & SD & T-Tests & Indication level \\
\hline Paper and pen & Humanitarian & 167 & 3.88 & 0.05 & 0.76 & 0.08 & 0.93 \\
evaluation & Scientific & 201 & 3.88 & 0.05 & 0.79 & & \\
\hline Performance-based & Humanitarian & 167 & 3.95 & 0.05 & 0.69 & 0.77 & 0.44 \\
evaluation & Scientific & 201 & 3.90 & 0.05 & 0.74 & & \\
\hline Observation & Humanitarian & 167 & 3.96 & 0.06 & 0.86 & 0.03 & 0.97 \\
evaluation & Scientific & 201 & 3.95 & 0.06 & 0.86 & & \\
\hline Self-Review & Humanitarian & 167 & 4.03 & 0.05 & 0.61 & 0.77 & 0.96 \\
Assessment & Scientific & 201 & 4.04 & 0.05 & 0.70 & & \\
\hline Communication & Humanitarian & 167 & 41.55 & 0.56 & 0.34 & 0.67 & 0.50 \\
evaluation & Scientific & 201 & 41.05 & 0.48 & 6.80 & & \\
\hline Total & Humanitarian & 167 & 4.00 & 0.04 & 0.58 & 0.34 & 0.73 \\
& Scientific & 201 & 3.97 & 0.04 & 0.67 & & \\
\hline
\end{tabular}

There are no differences in the total or in the fields attributed to the major (humanitarian or scientific)

\section{Discussion}

The results related to the first question were obtained by calculating the numbers, arithmetic means and standard deviations of the responses of the study sample members to the test items according to the fields of study, and the overall score that expresses the degree of use of realistic evaluation among teachers of the higher basic stage in the Aljama' a district.

The degree of using realistic evaluation in all fields among teachers of the higher basic .stage in the Aljama' a district was great and, the researcher attributes the reason for this to the tendency in the new educational system in Jordan to use new strategies in education and evaluation to develop the educational process in schools, and this application is reflected in public and private schools, including international schools, and because teachers of the higher basic stage in international schools adopt the foreign system in education, the use of realistic evaluation strategies was appropriate and appropriate to the nature of education in the foreign system.

It must be noted that the courses dealing with this type of evaluation are subjected to international school teachers more than once during the academic year, and therefore teachers have become more open and aware of the importance of this evaluation, and therefore it has become a behaviour that they practice with high efficiency, as teachers have a major role in change for the better, as a result of their feeling the weight of the trust placed on them.

The researcher attributes the gradation in arithmetic means of realistic evaluation strategies that reflect the interaction between the teacher and the student in the evaluation process, as the use of the paper-and-pencil assessment strategy is considered the least effective between the student and the teacher and depends mainly on knowing the degree of knowledge that the student acquired through the test, while the evaluation strategy is the most effective through communication. As the student expresses his thoughts and information directly through the question and the answer.

It is worth noting that, in the current period, interest in the process of distance learning has increased due to the current circumstances due to the Corona pandemic, and therefore the communication calendar emerged as one of the main components of the current calendar, and therefore agrees with the results of this study, as the degree of use was very large at the time the questionnaire was distributed

The results of the first question are consistent with the study of Al-Zaubi (2013), which showed that a large percentage of teachers practice realistic evaluation strategies, and the study of Al-Bashir and Barham (2008) confirmed that the teacher uses alternative evaluation strategies because of their role in improving his skills.

The current study differed with the study of Al-Ghamdi (2013), whose results showed that teachers need training programs in the methods of using realistic evaluation, in addition to its difference with the results of a study (Awawda, 2015), which showed that there were few teachers using the alternative (realistic) method of evaluation.

The second question was answered by counting the numbers and arithmetic means and standard deviations, then, the use of multiple binary variance analysis. It is noted that there are differences attributed to gender in the 
overall tool, where the arithmetic mean was $(3.71)$ at $(\mathrm{a}=0.05)$, and in the third domain (observation evaluation strategy) where the(arithmetic mean was $=11.07$ ), and the fourth domain(self-review evaluation strategy) where the (arithmetic mean was $=11.02$ ) and the fifth domain (communication evaluation strategy) where the (arithmetic mean was $=724.06$ ) in favour of females, and there are no differences attributed to years of service, and there are no differences attributed to the interaction between gender and years of service to the degree of use of international schools teachers of realistic evaluation methods in the upper elementary stage.

The results can be attributed, that is, the reason for the differences in favour of females, to that female teachers - according to some occasional personal meetings and observations by the researcher for fellow teachers - have a greater tendency towards interacting with students and using the new methods of evaluation and that they are keen to attend conferences and workshops and developmental training expected of males, and to that the school administration in female schools is more in the implementation of educational instructions and guidelines, and that teachers are more committed to implementing them.

This study is in agreement with the study of Al-Zaubi (2013), where it showed differences in the degree to which mathematics teachers practice realistic evaluation strategies, where it attributed to the gender variable in favor of the female teachers. This study differed with the study of Al-Bashir and Barham (2008), which showed that there were no statistically significant differences between the arithmetic means of the degree of teachers 'response to the use of alternative evaluation strategies due to the gender variable.

The researcher attributes the reason for the absence of statistically significant differences for the variable years of service to the fact that teachers of all years of service have a tendency to develop teaching and evaluation methods and keep pace with the Ministry's directions, and the majority of the study sample were with service ranging from 5 to less than 10 years and more This weakened the impact of the service variable. This result was in agreement with the study of Al-Zaubi (2013) which showed that there were no differences in the degree of practice by mathematics teachers of realistic evaluation strategies that were attributed to the variable of years of service, and it differed with the study of Al-Bashir and Barham (2008), which showed that there are differences between the arithmetic means of the degree of teachers 'response to the use of alternative evaluation strategies and tools. This is due to the variable years of service for the benefit of teachers with service from (1-5 years).

The third question was answered by calculating the arithmetic means and the standard deviation of two independent samples (humanitarian and scientific). To verify the differences between the human and scientific specialization, as international school teachers use realistic evaluation methods, parametric tests were used(tTest). The results indicated that there are no statistically significant differences in the degree to which international school teachers use realistic evaluation methods in the higher basic stage with different academic specializations.

The researcher attributes the reason for the absence of statistically significant differences in the arithmetic means to the extent of using realistic evaluation among teachers of the higher basic stage in international schools in the Aljama' a district, is due to that teachers in the study community and their different specializations are going through the same educational conditions for teaching. They are subject to training courses, each according to his specialization, in addition to following the developments in the educational process, in terms of the development of evaluation tools.

Realistic evaluation is a strategy and an evaluation method that is suitable for all stages and all academic subjects and educational curricula, and they are aware of the different specializations in the role of realistic evaluation. For students and for them as well as teachers.

This study was in agreement with the study of Al-Bashir and Barham (2008), which showed no significant differences among the arithmetic means of the degree of teachers 'response to using alternative evaluation strategies that is attributed to the specialization variable

\section{Conclusion and recommendations}

Based on the previous results, the study recommends the following:

1- Continuing to use realistic evaluation in all of his strategies in the upper primary stage.

2- Administrators should reinforce and encourage teachers to use realistic evaluation as an alternative to the traditional evaluation.

Based on the previous results, the study suggests the following:

1- Realistic evaluation has a great impact on increasing the interaction between the teacher and the student and thus increasing the desired results from the teaching process.

2- Conducting a similar study that uses other methods to collect data on the topic such as observation, and others, to investigate the degree to which teachers practice realistic evaluation strategies and tools, with the introduction of other variables in the study design such as: geographical environment, beliefs teachers, managers, and supervisors and their attitudes towards employing realistic evaluation strategies and tools.

3- The researcher proposes to train teachers of the upper primary stage of various degrees on preparing and 
employing realistic evaluation tools.

4- Preparing specialized programs to train teachers of the upper primary stage with different degrees of education in the use of realistic evaluation strategies especially the communication evaluation strategy.

5- Conducting more studies on the relationship between the use of realistic evaluation by teachers on other samples different from the current study and using different variables.

6- Adopting a professional development plan for teachers at all physical, moral technical, research, educational and educational levels, and providing them with the opportunity to familiarize themselves with international models in the field of evaluation and to prepare educational research, which will lead to an increase in the degree of their own professional development.

7- Allocating rewards for creative teachers by evaluating educational supervisors of the degree of professional development of these teachers.

\section{Acknowledgements:}

The authors wish to thank Dr Raed M. Kanan for his contribution in editing and data analysis, Mrs. Ola B. Bawab, Mrs. Ayat M. Omran and Miss Tamara T. Al-Shobaki for their contributing in design the tool and preparing the required documents for authorities.

\section{References}

Al-Bashir, A., \& Barham, A. (2012), "The Use of Realistic Evaluation Strategies and Tools in Evaluating Mathematics Learning and the Arabic Language in Jordan”, Educational Sciences Journal 13 (1), 241-270.

Posner, G. (2016), "Curriculum analysis. (Translated by Majdi Suleiman Al-Mashaelah)”, P.O. Box 183520 Amman 11118 Jordan

Jaber, J. (2006), "Contemporary trends and experiences in evaluating student and teacher performance", Cairo: Arab Thought House, 94 Abbas El Akkad Street, Egypt.

Al-Zaubi, A. (2013), "Degree of knowledge and practice of mathematics teachers for realistic evaluation strategies and tools", Journal of the Islamic University for Educational and Psychological Studies 21 (3), $165-197$.

Zaitoun, H. (2003)," Teaching Strategies: A contemporary view of teaching and learning methods", Cairo: The World of Books, 11518, Cairo Governorate, Egypt

Abboud, Y. (2016), "Alternative evaluation as a modern trend in evaluating student performance. Working paper", International Conference: The Teacher and the Age of Knowledge, Opportunities and Challenges, Kingdom of Saudi Arabia.

Awawda, I. (2015), "The degree of practicing realistic evaluation strategies among middle school teachers in Dammam Governorate", Taibah University Journal for Educational Sciences 11 (1), 43-59.

Al-Ghamdi, H. (2013), "A proposed training program for professional growth for middle school science teachers in light of international standards and the requirements of improved science curricula", (unpublished PhD thesis), Umm Al-Qura University, Kingdom of Saudi Arabia

Mansour, M. (2007), "The challenges of educational globalization related to the school and ways to confront it", Cairo, the comprehensive library.

Al-Mousa, A. (2014). "Technology in the service of learning and education", House of Arab Renaissance, 32 Abdel Khaleq Tharwat Street, Cairo, Egypt.

Ministry of Education, (2013), "The framework General curriculum and evaluation", Amman: Curriculum and Textbooks Department, Jordan.

Al-Mahrooqi R., \& Denman C. (2018), "Introduction. In: English education in Oman", (vol 15), Singapore. Springer, English Language Education. ISBN 978-981-13-0265-7.

Bantulo, J., Eugenio, S., \& Guhao, J. (2016), "Standpoints of learners of the adult learning system: a phenomenology", International Journal of Scientific \& Engineering Research 7 (11), 342-362.

Gottlieb, M. (2016), “Assessing English language learners: bridges to educational equity: connecting academic language proficiency to student achievement", Thousand Oaks, CA: Corwin, xxi +268.

Krejcie R., \& Morgan D. (1970), "Determining Sample Size for Research Activities", Educational and Psychological Measurement 30, 607-610.

Nasri, N., Roslan, S., Sekuan, M., Bakar, K. \& Puteh, S. (2010)," Teachers' Perception on Alternative Assessment",. Procedia - Social and Behavioral Sciences 7. 37--42.

Tindowen, D., Bassig, J. \& Cagurangan, J. (2017), “Twenty-first-century skills of alternative learning system learners", SAGE Open. 7 (3).

Wiggins, G. \& McTighe, J. (2006)," Examining the teaching life", Educational Leadership 63, 26-29.

Abdel Hay, I. (2017). 6 new models to evaluate student learning (Online), available: https://www.new-educ.com/.

Al-Kubaisi, H. (2014), "Systems Approach Education". (Online), available: https://altadreeb2010/blogspot.com/2014/04/blog-post_25.html 